\title{
Professional deficits of a graduate of a Pedagogical University: from identification to reimbursement
}

\author{
Sergey Alekseev, Natalia Zhdan, Oksana Kiryash, and Tatyana Rabochikh \\ Omsk State Pedagogical University, Omsk, Russia
}

\begin{abstract}
The paper reveals the issues of organizing postgraduate support of graduates of a pedagogical university through the interaction of the Extended Education Institution and specialized departments of OSPI. The construction of a system of postgraduate support is based on the results of diagnostics of professional deficiencies of young educators. The proposed content and forms of organization of training ensure the choice of an individual educational route for a young educator and the elimination of existing deficiencies.
\end{abstract}

\section{Introduction}

Today, the education system more than ever needs a competent, responsible educator, acting in accordance with state policy and the principles of psychological and pedagogical science. The issues of the professional development of young educators are most often raised and discussed in the focus of the shortcomings of novice teachers - they do not know how, do not know what, do not apply, do not want, etc. After graduating from a higher educational institution, a young teacher is not yet a professional in his/her field; he/she has a certain path of professional development, "getting used" to the profession. E.A. Klimov argues that if at these stages, the employee has not entered the professional community as a full-fledged member, most likely, he/she leaves the profession. [1] Therefore, it is important for a young teacher to find his/her place, to adapt, to acquire the skills to quickly enter the profession - all this determines the relevance of our research.

Scientific works in the field of labor psychology and professional activity by E. A. Klimov [1], Yu. P. Povarenkov [2], A. K. Markova [3], E. F. Zeer [4] and other scholars in the field of professional development of young specialists are of considerable interest for our work.

Yu. P. Povarenkov in his research found that the first stage of professional development is implemented in a passive model, when the leading role in the structure of the situation is assigned to professional requirements, which, as it were, "lead" professional development through the restructuring of the situation, through the formulation of new tasks of professional development. [2] A. K. Markova calls the studied stage a period of selfactualization, during which a person masters the rules, norms, professional activity, and professional communication, which, in general, forms a kind of subject and psychological professional norm. [3] E. F. Zeer [4] noted that only after the completion of adaptation, internal, psychological factors begin to play a leading role in the determination of 
professional development. During this period, the subject begins to focus not on the professional, but on his/her own requirements, which are correlated with the professional capabilities of the subject himself/herself.

\section{Materials and methods}

The methods of obtaining information on the problem under study were theoretical analysis of scientific literature, logical-semantic modeling of the process of professional development of an educator. The collection of empirical data was carried out by analyzing the documents: FSEI HE 3++ undergraduate in the direction of training 44.03.01 "Pedagogical Education", the professional standard "Teacher", which made it possible to identify the requirements for the qualification "Teacher"; by the method of "focus groups" a complex of deficits of young educators has been determined.

Analysis of the literature has shown that today, "the question is whether the teacher is qualified enough to solve the problems facing him/her in the conditions of informatization, growing competition, and permanent transformations in the field of education" [4]. The scientific community pays close attention to this aspect, an example of which is the number of studies devoted to these issues [5-7]. For example, a study conducted by the Scientific and Methodological Center, MBEI SVE, in Kemerovo in 2015. The results of the study have shown that "a significant part of young educators experience difficulties in the "execution of documentation, reporting'" (35.4\%). Also, one of the problem areas in the work of a young teacher is "communication with the parents of students" (such a choice was made by $31.3 \%$ of the respondents) and the lack of experience provokes difficulties in 'conducting extracurricular activities' in 27.1\%" [8].

Analysis of the data of the all-Russian study of the success of adaptation of young teachers of educational organizations conducted in 2017 has revealed that "among the difficulties in the implementation of professional activities, young educators have identified: lack of time $-26.4 \%$, lack of experience in working with children-17.0\%, lack of ability to plan their activities and to allocate resources - $6.7 \%$; lack of understanding on the part of parents-8.6\%, which indicates insufficient psychological and pedagogical preparedness for the implementation of professional pedagogical activity" [9].

In 2020, as a part of the implementation of the Employer Strategic Project, young educators and employers of educational organizations in the city of Omsk and Omsk Region took part in the study. The use of the focus group method made it possible to collect subjective information from its participants-representatives of the administration, teachers-mentors of educational organizations, and young educators-graduates of Omsk State Pedagogical University. Analysis of the results of a group, focused interview in the form of a group discussion made it possible to identify the professional deficiencies of young educators provided in Table 1.

After analyzing the data of a number of similar studies and the results of focus groups, we can say that some of the deficits for young educators are "stable": difficulties in establishing contact with students' parents, working with documentation, organizing extracurricular work with students, etc. But at the same time, new deficits appear which are noted by young educators: planning and organizing the activities of students with special educational needs, the use of e-learning and distant learning technology (DLT) for organizing various types of activities in the educational process, etc.

\section{Results and discussions}

The identified deficiencies have a number of features: 
- when considering the managerial aspect of the educational process, young educators note difficulties only in goal-setting and organization. There is no reflection on the control function, which is reduced by them, mainly, to the preparation of students for BSE and USE;

- most of the identified deficiencies are associated with the subjects, instead of the objects of the educational process;

- for young educators, significant difficulties are caused by an insufficient level of formation of communicative competencies.

In order to organize targeted activities to eliminate the identified deficiencies and to prepare young educators for professional activities under the requirements of the occupational standard (OS) and NSTS (National System of Teacher Growth), we have correlated the identified deficiencies with the types of professional qualifications (PQ) offered in NSTS (Table 1).

Table 1. Correlation of professional deficits with the types of professional qualifications (PQ) offered by the NSTS

\begin{tabular}{|c|c|c|}
\hline \multicolumn{2}{|c|}{ Deficits allocated by } & \multirow{2}{*}{$\begin{array}{l}\text { Determination of deficits, } \\
\text { according to OS } \\
\end{array}$} \\
\hline employers & young educators & \\
\hline \multicolumn{3}{|c|}{ Subject professional qualification } \\
\hline $\begin{array}{c}\text { Insufficient } \\
\text { knowledge of FSES and } \\
\text { KMM to USE and BSE }\end{array}$ & $\begin{array}{l}\text { Insufficient knowledge of FSES } \\
\text { and KMM to BSE, USE }\end{array}$ & $\begin{array}{l}\text { The content of FSES requirements } \\
\text { for the subject results of mastering MC } \\
\text { at the basic and specialized levels }\end{array}$ \\
\hline \multicolumn{3}{|c|}{ Psychological and pedagogical professional qualifications } \\
\hline \multirow[t]{2}{*}{$\begin{array}{c}\text { Difficulty } \\
\text { scheduling training } \\
\text { sessions }\end{array}$} & \multirow[t]{2}{*}{$\begin{array}{l}\text { Lack of knowledge in planning and } \\
\text { organizing extracurricular activities. } \\
\text { Working with children with } \\
\text { deviant behavior, children with } \\
\text { retarded mental development. } \\
\text { Homeroom teacher job. } \\
\text { Lack of knowledge and practice in } \\
\text { the field of developmental psychology, } \\
\text { communication psychology }\end{array}$} & $\begin{array}{c}\text { Planning, organization, control of } \\
\text { the implementation of metasubject } \\
\text { programs: } \\
\text { - formation (development) of } \\
\text { ULA; } \\
\text { - education and socialization, } \\
\text { in lesson and extracurricular activities, } \\
\text { including when performing the } \\
\text { functions of a homeroom teacher. }\end{array}$ \\
\hline & & $\begin{array}{l}\text { Planning and organizing the } \\
\text { activities of students with special } \\
\text { educational needs, including with } \\
\text { health related conditions }\end{array}$ \\
\hline \multicolumn{3}{|c|}{ Methodical professional qualification } \\
\hline $\begin{array}{c}\text { Insufficient } \\
\text { knowledge of } \\
\text { methodological tools }\end{array}$ & $\begin{array}{l}\text { Development of work programs, } \\
\text { curriculum plans, plans for } \\
\text { extracurricular activities (in the } \\
\text { subject). } \\
\text { Methodology for preparing for } \\
\text { SFE (BSE and USE) (by subject) }\end{array}$ & $\begin{array}{l}\text { Development of work programs, } \\
\text { curriculum plans, plans for } \\
\text { extracurricular activities (in the } \\
\text { subject). } \\
\text { Methodology for preparing for } \\
\text { SFE (BSE and USE) (by subject) }\end{array}$ \\
\hline \multicolumn{3}{|c|}{ Communicative professional qualifications } \\
\hline $\begin{array}{l}\text { Insufficient level } \\
\text { of development of } \\
\text { communicative } \\
\text { competencies } \\
\text { (prevention and } \\
\text { resolution of conflicts, } \\
\text { communication with } \\
\text { subjects of educational } \\
\text { activities). }\end{array}$ & $\begin{array}{c}\text { Lack of legal literacy. } \\
\text { Prevention and resolution of } \\
\text { conflicts with subjects of educational } \\
\text { activity. } \\
\text { Inability to work with documents } \\
\text { (maintaining electronic journals, plans } \\
\text { for extracurricular activities, etc.). } \\
\text { Lack of sufficient skills to organize } \\
\text { e-learning and DLT. }\end{array}$ & $\begin{array}{l}\text { Implementation of regulatory } \\
\text { requirements in the implementation of } \\
\text { professional activities. } \\
\text { Maintaining documentation that } \\
\text { ensures the implementation of working } \\
\text { (educational, subject) and metasubject } \\
\text { programs, personal files of students, } \\
\text { etc. } \\
\text { Interaction with subjects of } \\
\text { educational activity. } \\
\text { Application of e-learning and } \\
\text { DLT. }\end{array}$ \\
\hline
\end{tabular}

Analysis of the data presented in the Table makes it possible to note that young educators, to varying degrees, experience a deficit in all types of professional 
qualifications: subject, psychological and pedagogical, methodological, communicative. The identified deficiencies once again highlighted the problem of the Russian educational system: "the separation of professional and educational qualifications, as opposed to the experience of other countries". [10] In order to solve this multifaceted problem, it is necessary to develop a system of interaction "university - educational organization - young educator".

Omsk State Pedagogical University is implementing the Employer Strategic Project. The project is aimed at identifying professional and pedagogical deficits experienced by young educators - graduates of the pedagogical university in the performance of labor functions and creating conditions for continuous professional development.

During the implementation of the project, it is planned to solve the following tasks:

1. Studying the opinion of employers, educators-mentors, young educators about the advantages and disadvantages of training young educators for the implementation of professional and pedagogical activities.

2. Development of proposals for adjusting the basic educational programs of higher education.

3. Development and implementation of additional professional training programs (including modular personalized ones for young educators) in relevant areas of professional development of teachers.

4. Planning and implementation of events for postgraduate support of graduates of the pedagogical university.

In order to plan and to implement the system of interaction "university - educational organization - young educator", the Calendar of Events of the Employer Strategic Project, which reflects the content of events and the forms of their implementation, has been developed. A fragment of the Calendar of Events is provided in Table 2.

Table 2. Calendar of Events of the Employer Strategic Project for 2021 (fragment)

\begin{tabular}{|c|c|c|}
\hline \multirow{2}{*}{ Name of professional deficits } & \multicolumn{2}{|c|}{ Activities aimed at reimbursement of professional deficits } \\
\hline & Name (topic) & Form \\
\hline \multicolumn{3}{|c|}{ Subject professional qualification } \\
\hline $\begin{array}{l}\text { The content of FSES requirements for } \\
\text { the subject results of mastering MC at } \\
\text { the basic and specialized levels }\end{array}$ & $\begin{array}{l}\text { Some types of problems of increased } \\
\text { difficulty in USE format in mathematics }\end{array}$ & seminar \\
\hline \multicolumn{3}{|c|}{ Psychological and pedagogical professional qualifications } \\
\hline \multirow{3}{*}{$\begin{array}{l}\text { Planning, organization, control of the } \\
\text { implementation of metasubject } \\
\text { programs. } \\
\text { Organization of project activities of } \\
\text { students in lesson and extracurricular } \\
\text { activities }\end{array}$} & Features of a modern lesson. & $\begin{array}{l}\text { business } \\
\text { game }\end{array}$ \\
\hline & $\begin{array}{c}\text { Development and evaluation challenges for } \\
\text { regulatory ULAs }\end{array}$ & lecture \\
\hline & Organization of project activities of students & $\begin{array}{l}\text { seminar- } \\
\text { workshop }\end{array}$ \\
\hline \multicolumn{3}{|c|}{ Methodical professional qualification } \\
\hline $\begin{array}{l}\text { Development of work programs, } \\
\text { curriculum plans, plans for } \\
\text { extracurricular activities (in the subject) }\end{array}$ & $\begin{array}{l}\text { Modern approaches to the organization of } \\
\text { extracurricular activities at school }\end{array}$ & $\begin{array}{l}\text { dialogue } \\
\text { platform }\end{array}$ \\
\hline $\begin{array}{l}\text { Methodology for preparing for SFE } \\
\text { (BSE and USE) (by subject) }\end{array}$ & $\begin{array}{l}\text { Preparing school graduates for the BSE and } \\
\text { USE in Russian language and literature }\end{array}$ & seminar \\
\hline \multicolumn{3}{|c|}{ Communicative professional qualifications } \\
\hline $\begin{array}{c}\text { Interaction with subjects of educational } \\
\text { activity }\end{array}$ & $\begin{array}{l}\text { Psychological and pedagogical features of } \\
\text { interaction with students, parents. }\end{array}$ & training \\
\hline
\end{tabular}

Revealing the deficiencies of young educators and determining their structure make it possible to determine the development of the communicative competence of young specialists - graduates of Omsk State Pedagogical University - as the main direction of the interaction system "university - educational organization - young educator". The main 
forms of interaction should be practice-oriented seminars (webinars) using active forms of learning, dialogue platforms, trainings, master classes, professional contests, allowing to create conditions for the manifestation of the young educator's own position, the application of his/her knowledge and skills to solve the relevant tasks arising in professional activity. Particular attention to the development of communicative qualifications should be paid to the use of distance learning technologies.

The use of modern distance educational technologies and e-learning systems in organizing the interaction "university - educational organization - young educator" allows attracting the maximum number of young educators to the activities of the Employer Project, as well as building an individualized educational route for professional development through a system of lectures, seminars, trainings, online and offline consultations.

\section{Conclusions}

The analysis of scientific works on the issues of professional development and practice of working with young educators, as well as the results of our own research, suggest that, as the conditions for compensating for the professional deficits of young educators, one should consider not ready-made forms that are difficult to transfer from one territory to another, but pedagogical strategies, which, depending on the objective situation of a particular territory, can be implemented in different forms.

As a part of the implementation of the interaction system "university - educational organization - young educator", the Extended Education Institution has combined the activities of the specialized departments of Omsk State Pedagogical University for postgraduate support of graduates, intensified contacts with the administration and educators-mentors of educational organizations.

An important condition and means of prompt identification and reimbursement of professional deficiencies of young educators is the use of e-learning and distance learning technologies.

\section{References}

1. E.A. Klimov, Psychology of Professional Self-Determination: a Training Manual for Students of Higher Educational Institutions, 304 (2010)

2. Yu.P. Povarenkov, Siberian Psychological Journal, 24, 53 (2006)

3. A.K. Markova, Psychology of Professionalism, 312 (1996)

4. E.F. Zeer, V.S. Tretyakova, V.I. Miroshnichenko, Education and Science, 21(6), 93 (2019)

5. E.P. Borodina, A.L. Borodin, How to Help a Young Educator in His/Her Professional Growth?, 2, 376 (2018)

6. N.P. Sazonova, E.V. Koltygina, N.V. Novikova, Bulletin of Altai State Pedagogical University, 1(38), 22 (2019)

7. A.S. Mamatkova, Problems of Science and Education, 19(103), 29 (2020)

8. G.T. Vasilchuk, I.V. Ionas, Materials of the II Interregional Scientific and Practical Conference, (2015) http://nmc-kem.ru

9. E.G. Chernikova, T.G. Ptashko, A.V. Rudenko, Bulletin of Chelyabinsk State Pedagogical University, 7, 114 (2017)

10. O.N. Oleinikova, A.A. Muravyova, N.M. Aksenova, Education and Science, 20(6), 70 (2018) 